\title{
FROM ENLARGEMENT TO BREXIT. THE ROAD OF GREAT BRITAIN WITHIN THE EU AND THE ROAD OF THE EU WITHOUT GREAT BRITAIN
}

\section{Anamaria Loredana IANOȘI}

Ph.D.

Faculty of European Studies,

Babeş-Bolyai University Cluj-Napoca

felderean_anamaria@yahoo.com

\section{DOI:10.24193/OJMNE.2017.24.06}

\begin{abstract}
This study aims to analyze the main aspects of the relationship between Great Britain and the European Union (EU) from the time of accession (1973) up to the time of Brexit's initiation (2016) and to outline the future relationship between them, after the exit procedure of Great Britain from the EU (2019) is finished. In this context, the attention will be directed toward classifying the relations between Great Britain and the EU, from a historical perspective in an attempt to identify the premises that contributed tacitly to the choice of the British to withdraw from the EU. The study then continues with a radiography of the ante and post Brexit events, in order to try to contribute to solving the most important problems caused by Brexit: setting the borders of Great Britain and Ireland, determining Great Britain's bill concerning the "divorce' from the EU and last but not least, establishing the situation of European citizens settled in Great Britain and of British citizens settled in the EU countries. A special section of this study is dedicated to summarizing the future socio-economic-politicalcultural relations between Romania and Great Britain. The end of the study is dedicated to the presentation of the Brexit phenomenon as cultural element in the Community, met in painting, literature and theatre, form of manifestation generally embraced by the British supporters of Great Britain's remaining in the EU, who succeeded to create, combining reality with fiction, true works of art in every sense of the word.
\end{abstract}

Keywords: Brexit, historical perspective, new borders, Great Britain's bill, the status of the EU citizens, the British-Romanian relations, Brexit as element of culture.

\section{Introduction}

Without doubt, 2016 was a very important year throughout the whole European Community and will certainly become a reference year in the history of the EU. 
Issue no. $24 / 2017$

After the great widening and deepening of European integration in 2004 and 2007, after overcoming the devastating effects of the financial crisis of 2007-2010, which has affected all Member States, in particular, Greece, has led to the creation of the Grexit phenomenon, after Croatia joining the EU in 2013, after the considerable efforts made by the European Union in solving the crisis of refugees, the increasing terrorist attacks, while facing the cooling of relations with the United States of America as a result of the setting up of the Trump Era and with Russia's new political ambitions, the European Union was faced with effect from 2016 with a new challenge: Great Britain unexpected withdrawal from the European project, after more than 44 years of membership. Thus, 2016 is by far the year of Brexit, an unprecedented event for the EU, from its creation until today. The withdrawal of a Member State from the EU structure is an event that many of us have never believed we will be witnessing, but yet we have been.

The inevitable uncertainty caused by the separation of Great Britain from the EU has generated many questions that require prompt answers. Why did Great Britain decide to leave the EU? What was the triggering factor? How will the European project continue without the British State? What will be the new relations between the two actors? What agreements will be maintained? What understandings will be discarded? What new arrangements will be signed? How will the new EU borders look like? What will happen with the EU citizens established in Great Britain? What will happen with the relations between Great Britain and Romania? What will happen with the Romanians living in Great Britain? are certainly the most up-to-date questions of the moment. In this study, an effort will be made to answer these questions. In order to do this, will be analyzing the Great Britain's course within the EU, before and after the waves of accession in 2004 and 2007. To identify the cause for the breakup of Great Britain from the EU, the speeches of British and European officials will also be analyzed.

Also, for a better understanding of the Brexit paradigm, particular attention will be paid to the British Referendum and to the progress of Great Britain and of the EU in creating a new framework for cooperation between them from their new positions: The EU - 27, and Great Britain in its new position of non-Member State of the European Union. 
Issue no. $24 / 2017$

"Brexit" phenomenon and the way in which this will be finalized in 2019, will have a significant impact on the future of the European Union, which is currently at the cross-roads. Last but not least, an aspect at least interesting on Brexit is represented by the fact that it has exceeded the political-economic-social boundaries, being found more often in the cultural space in which artists excel in presenting its negative facets for Great Britain and its citizens, some of the scenarios having apocalyptic features for the future of the United Kingdom, which will pay a huge price for the inability to form a membership and a true European solidarity in the best four decades at their disposal.

The results of the research, as we shall see, indicate that there is a common will from Great Britain and the EU to settle the issue of divorce in the most amiable terms, the stake being to establish the best possible future relations of cooperation between the two actors.

\section{Great Britain's road within the EU}

As noted in the history of the European construction, in 1951, six European states: France, Germany, Italy, Holland, Belgium and Luxembourg, known in literature also under the name of "Inner Six", have signed the Paris Treaty establishing the European Coal and Steel Community (ECSC), and in 1957 were signed the Treaties of Rome establishing the European Economic Community (EEC) and the European Atomic Energy Community (EAEC). Ten years later, the three structures have operated under the name of "European Communities" (EC). The British course along with the EU got off on the wrong foot, in 1963, when the United Kingdom of Great Britain has requested for the first time accession to the EC, request that was denied vehemently by the French president Charles de Gaulle. Four years later, the integration of Great Britain is again blocked by the French president.

Thus, in 1967, Charles de Gaulle is again retelling a determined "no" for the British to access to the common market. During a press conference at the Elysée Palace in Paris on November 27, 1967, Charles de Gaulle warned the five partners that if they will support the accession of Great Britain, to the detriment of the contrary French will, this will result in the dissolution of the European Community (BBC, n.a., 1967). Also, General De Gaulle accused Great Britain of a deep hostility toward the European construction, stating that London has shown for a long time, a total lack of interest for the common market and in order to be part 
Issue no. $24 / 2017$

of this, Great Britain should operate major changes prior to its accession to the EC, because the Great Britain's economy is incompatible with the common market of the six Founder States of the EC (BBC, n. a., 1967).

He listed the aspects of the British economy which are incompatible with the member status, the most important aspect highlighted being that of the British practices in the field of agriculture. The President of France did not opposed the trade with Great Britain, if they had been carried out through an association between Great Britain and the EC, but nothing more (BBC, n.a., 1967). With this approach, Charles De Gaulle didn't let any hope to the British Prime Minister, Harold Wilson to join the EC in the near future.

Great Britain's chance to become a Member State has reappeared after Charles De Gaulle was forced to give up the presidency of France in 1969 and, therefore, on October 17, 1972, the British Conservative Prime Minister Edward Heath signed the Treaty of Accession of the United Kingdom of Great Britain to the EC, becoming a Member State with full rights on January 1, 1973, together with Ireland and Denmark, event celebrated with great enthusiasm in Brussels (BBC, n.a., 1973).

Thus, in Brussels at midnight on January 1, 1973 was raised a "Union Jack" flag to mark the enlargement of the European Union from six to nine member states. Prime-Minister Edward Heath showed his optimism about the British success, considering that the Union will bring prosperity to the country. He said: "It will be a gradual development and, obviously, things will not happen overnight. But from the point of view of our everyday lives we will find there is a great cross-fertilisation of knowledge and information, not only in business but in other spheres also. And this will enable us to be more efficient and more competitive in gaining more markets not only in Europe but in the rest of the world" (BBC, n.a., 1973: para. 6). The United Kingdom of Great Britain succeeds, after more than ten years of trying to be part of the European project, being very optimistic with regard to its great future in this structure. In the process, over 1000 British have relocated to Brussels to occupy their positions as public servants of the Community and the English language gradually became the common language of the Community, as Charles De Gaulle feared in 1963 and 1967 (BBC, n.a., 1973). Finally, the British have achieved the much desired and expected success. 
Issue no. $24 / 2017$

The happy marriage between the EC and Great Britain has lasted only two years. In 1975, in the context of the misunderstandings between the ruling Conservative Party and the opposition Labor Party, the divorce issue from the EEC emerged for the first time in Great Britain.

After the general elections in Great Britain since October 1974, the Labor Party wanted to renegotiate the conditions of accession of Great Britain to the EC and then to organize a referendum regarding leaving the community if the conditions were not enforced. After the changeover of power, the Labour Party has established itself as the ruling party and in spite of the distinct views of all major political parties in Great Britain and of the British press who have pleaded the for the British state to remain in the European Community structure, on the date of June 5, 1975 took place the first national referendum with regard to the exit of the Great Britain from the EC (May, 1998). After the referendum 67,2\% of the electorate voted to remain in the European structure (Becker, Fetzer, Novy, 2016). Great Britain's course next to the European Community has started to deteriorate since the time of the first referendum, Great Britain, thus becoming the EC's "strange partner" (Stephen, 1998, p. 6), whose own interests are wanted to be placed above the EC's interests. In 1983, the Labour Party has conducted a new election campaign on Great Britain's withdrawal, this time without a previous referendum, but after it has been defeated in the political fight, the party has changed its political approach toward the European project (Rajini, 2010).

Margaret Thatcher, Prime Minister of the United Kingdom between 1979-1990, militated throughout her term of office a Eurosceptic attitude, which has contributed to fuelling the discontent between the British country and the EC that would become the future EU on November 1, 1993. Euro scepticism has further developed in British politics. Thus, in 1993 the United Kingdom Independence Party (UKIP) was established, which adopted a strong Eurosceptic doctrine. UKIP has obtained the third place in Great Britain in the European elections in 2004, the second in the elections in 2009 and the first place in the elections in 2014 (Mason, 2014). UKIP's electoral success in 2014 was regarded often as a factor in support of the United Kingdom decision to leave the EU. 
Issue no. 24/2017

\section{Brexit: the beginning of the divorce between $\mathrm{UK}$ and $\mathrm{EU}$}

The Brexit means, according to the Oxford Dictionary: "the withdrawal of the United Kingdom from the European Union" after the referendum of June 23, 2016 (https://en.oxforddictionaries.com/definition/brexit). The Brexit or Brixit (the most recent version of the term) is an association of the terms British (or Britain) and exit, by analogy to the term Grexit (the possible exit of Greece from the Euro area or even from the EU, as a result of the adverse effects of the financial crisis). The term Brexit was used for the first time on May 15, 2012, by Peter Wilding, in a post on the Euroactiv blog, (Wilding, 2012). International press refers often at Peter Wilding with the appellation of "Mr Brexit", being famous for the fact that he sustained a smart Brexit that does not affect Great Britain's economy, issue which is very difficult to achieve in practice. Therefore, in the context of the crises in the Euro zone, fuelled by the migration problem and many other discontents, triggering Brexit was inevitable and the result announced in the morning of June 24, 2016 was one surprising: 51,9\% of the British have chosen to leave the EU permanently. This result has enabled the officials of this campaign to make the necessary arrangements to trigger Article 50 of the Treaty of Lisbon and to set the date of the definitive exit from the EU on March 29, 2019, the task being fulfilled by the Prime-Minister Theresa May: "Under the terms of Article 50, a country which invokes it automatically exits from the European Union after two years in the case in which the other 27 Member States do not agree unanimously, to extend the time limit" (Toma, 2017: para. 2). Also, in the future, the EU "will have to rewrite part of the philosophy of integration with the prospects of leaving the Community, a measure that already become operational through Brexit" (Păun, 2016 : 81). 
Issue no. $24 / 2017$

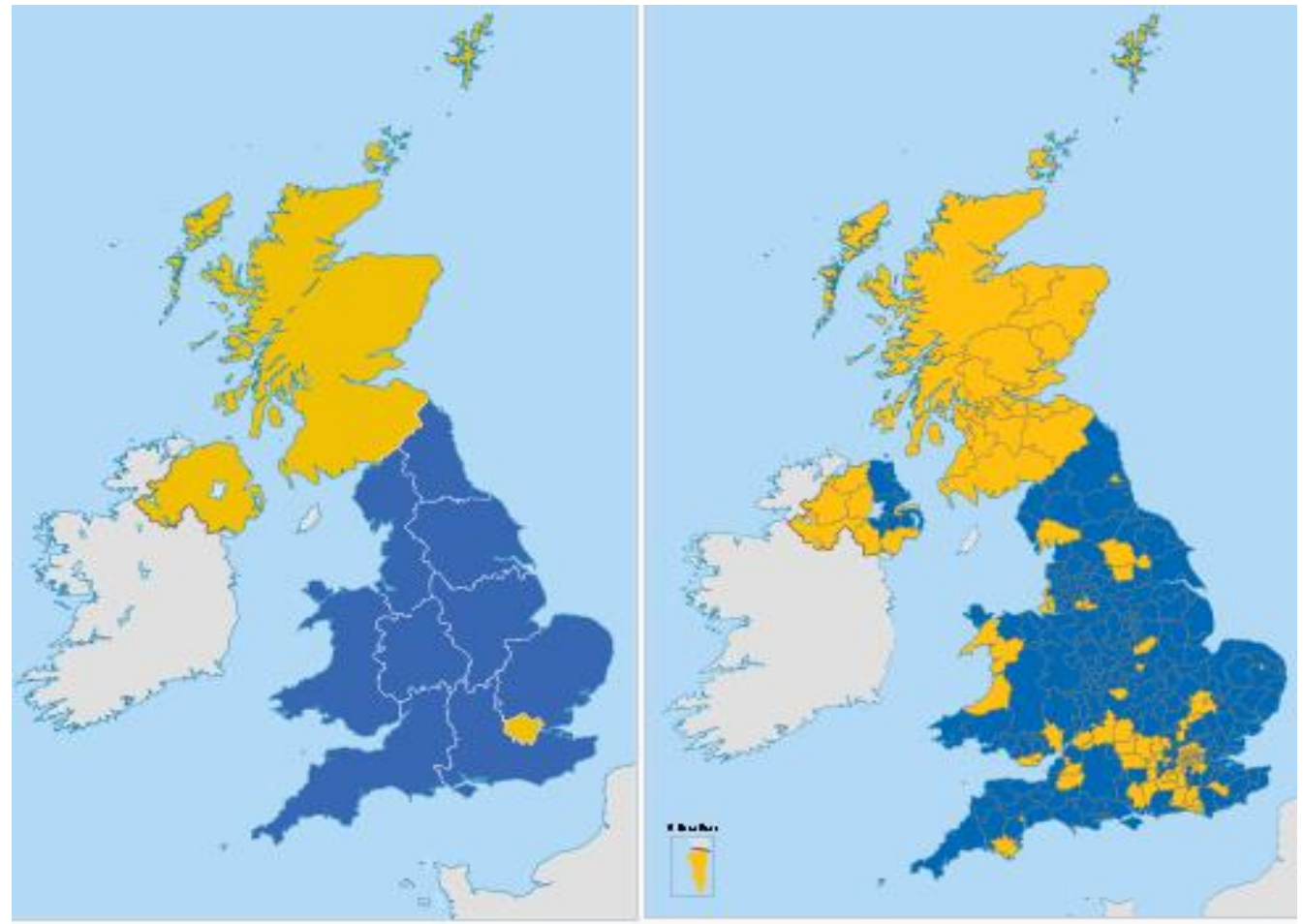

Results by region (left) and by local council district (GB) \& UK Parliament constituency (NI) (right)

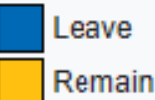

\begin{tabular}{|c|c|c|}
\hline \multicolumn{3}{|l|}{ National result } \\
\hline Choice & Votes & $\%$ \\
\hline Leave the European Union & $17,410,742$ & $51.89 \%$ \\
\hline Remain a member of the European Union & $16,141,241$ & $48.11 \%$ \\
\hline Valid votes & $33,551,983$ & $99.92 \%$ \\
\hline Invalid or blank votes & 25,359 & $0.08 \%$ \\
\hline Total votes & $33,577,342$ & $100.00 \%$ \\
\hline Registered voters and turnout & $46,500,001$ & $72.21 \%$ \\
\hline Voting age population and turnout & $51,356,768$ & $65.38 \%$ \\
\hline
\end{tabular}

Figure 1. The referendum in Great Britain, 2016 (Electoral Commission, https://www.electoralcommission.org.uk). 
Issue no. $24 / 2017$

In addition to the wave of questions which the Brexit triggered, within the negotiations on future relations between Great Britain and the EU were highlighted three important issues that require a common agreement and beneficial to both sides up to the date of March 29, 2019, the official date of Great Britain's definitive withdrawal from the EU. On the success of settling these three major Gordian Knots will depend the very type of collaboration that will be established between the two actors after 2019. The three key Brexit issues requiring immediate solutions are:

- to establish the functioning of the borders between the Republic of Ireland, an EU Member State and Northern Ireland, an integral part of the United Kingdom of Great Britain;

- the bill on which Great Britain must pay for the withdrawal from the EU;

- to establish the rights of European citizens in Great Britain (the most stringent issue of all).

Since the Brexit was initiated up to the present, were held five rounds of negotiations concerning a common agreement on the three essential aspects mentioned, but as we will see, without concrete results.

The first round of negotiations took place on June 19, 2017. Negotiations between Great Britain and the EU began in a constructive way. The two parties have agreed that Brexit to be carried out in an orderly manner: it was established the Brexit agenda which included organizational aspects, Brexit's priorities and a number of another four rounds of negotiations (Drăghici, 2017).

With regard to the first round of negotiations, Michel Barnier, the European Commission's representative in the discussion stated: "We wanted to establish the principles of the challenges associated with Great Britain's exit from the EU. A fair agreement is possible and will be much better than in the absence of an agreement. My main priority is to offer certainty concerning the rights of EU citizens who live in the UK and of the British citizens in the EU. It's about reciprocity, continuity, the absence of discrimination" (Drăghici, 2017: para 3).

What have the European Commission and Great Britain agreed to? According to the same sources, the British Prime Minister, Theresa May has expressed in the first round of 
Issue no. $24 / 2017$

negotiations, the wish that the border between Great Britain, Ireland and the European Union to be a unitary border after Brexit. The subject of the amount due by Great Britain to the Union, as a result of leaving the Community block has not been addressed in the first round of negotiations.

The second round of negotiations started on July 17, 2017 in Brussels and lasted four days. According to the European Commission's negotiator, Michel Barnier, the most debated topic was the one related to the rights of European citizens in the EU. At the end of the second round, according to Michel Barnier's statement, there remained a fundamental divergence between Great Britain and the EU on protecting the rights of European citizens, the EU wishing that such rights to be protected by the European Court of Justice and Great Britain by British legal courts, causing the danger that in the future Great Britain to amend the legislation to the detriment of European citizens living in the United Kingdom (Ionescu, 2017).

The third round of negotiations, carried out with effect from August 28, 2017, aimed at first to clarify the draft law of Brexit and the Irish border situation by London. The third round of negotiations started in a tense climate, the time pressure bringing dissatisfaction on both sides. Apart from Great Britain's position on the jurisprudence of national courts concerning the rights of European citizens established in their territory, London had not presented until that moment a clear position on the Brexit "bill" or on maintaining the same rights for Community immigrants in Great Britain of which they have received in the past (Popescu and Arustei, 2017). In the given context, the Europeans have refused to talk about a future commercial agreement with Great Britain before the conditions of its separation from the EU were established concretely.

The fourth round of negotiations held between September 25-28, 2017, practically resumed talks concerning the three major objectives of the EU (the border with Ireland, the bill and guaranteeing the rights of EU citizens) upon which no agreement has been reached in the previous round of negotiations. This time, it could be noticed a more cooperative attitude from the British Prime Minister Theresa May, from the British negotiator for Brexit, David Davis and his European counterpart, Michel Barnier. In this round was debated the issue of the financial debts which the United Kingdom has to pay to the EU. According to the 
Issue no. $24 / 2017$

European side, the financial regulations of the separation were estimated between 60 and 100 billion euros, while London, which has undertaken to pay the so-called "exit bill" assessed the amount due to 40 billion pounds (the equivalent of 45 billion euros), the amount representing the contribution to the European budget until 2020 and other commitments (Traci, 2017). Up to now, no agreement was reached clearly on Great Britain's bill, aspect that blocks the proper conduct of the negotiations between London and Brussels.

The most recent and the last round of negotiations, the fifth, took place between October 9-12, 2017, at the headquarters of the European Commission in Brussels. Although the expectations of both sides involved were high, the much-desired agreements on the 3 priorities of EU-27 which to allow the amicable separation from Great Britain have not been completed as desired, before the beginning of the works of the European Council of October 19-20, 2017 (Adevărul, n.a., 2017).

The end of the fifth round of negotiations has brought to light serious disagreements between the two protagonists of Brexit (Great Britain and the EU-27), which have so far failed to reach to a common position which to allow the conduct of the second phase of Brexit concerning the implementation of concrete measures of Great Britain's exit from the EU and of the negotiation of the trade agreements between the two sides. The means of guaranteeing European citizens' rights in the United Kingdom after Brexit remain the apple of discord between London and Brussels, in spite of the assurances received from the British State that they will be respected on the basis of the principle of reciprocity.

No doubt, it is true that the United Kingdom was a "difficult" partner in the EU structure, but it is also true that the leaving of the UK will mean for EU the loss of "the second largest net payer to the Eu budget and the country with the third largest population in the EU" (Dahl and Skomorokhova, 2017 : 277).

\section{The new relations between Great Britain and Romania, from the immigration perspective}

Although there is no official document in this respect, the British officials who undertook visits to Bucharest in the last few months have given assurances that the rights and freedoms of the Romanians established in Great Britain will be complied with. Boris 
Issue no. $24 / 2017$

Johnson, British Minister of Foreign Affairs stated during a meeting with his Romanian counterpart, Teodor Melescanu, on September 25, 2017 the following: "I don't think that they should be worried at all. They should not worry because they are extremely valuable members of our society. We love them. They have a huge contribution to the United Kingdom's economy, to the British culture. When you travel through London, you see a lot of Romanian shops, Romanians who work in all areas. We believe there are half a million of Romanians in the United Kingdom. We would be crazy to let them return to Romania. We want to keep them, we want to make sure that they feel safe and that their rights are protected" (Agerpres, n. a: para. 3).

In the interview given by the British official, he stressed the fact that after leaving the Community block, the United Kingdom will remain open for people with "talent, ambition and determination", but would like to control their immigration system in the future, in accordance with their own rules where the passport and visas will most likely be included after 2019.

As regards the Romanian-British bilateral relations, the British Embassy in Bucharest said in a press release that the United Kingdom wants to cooperate closely with Romania in the field of security and defense policies, of combating Russia's influence, of modern slavery, the drug trafficking and terrorism. At least at informal level, future relations between Great Britain and Romania seem to be good. If it will be so or not, it remains to be seen.

\section{The Brexit in Fine Arts, Literature and Theatre}

Although so far a common agreement between Great Britain and the EU has not been reached on the border of the Republic of Ireland, the Brexit's bill and the statute of European citizens in the United Kingdom or other equally important agreements on trade-related aspects between the two entities, agreements relating to the British airspace, fishing in the British maritime area and the Brexit's effects on British academic research, Brexit has gained important ground in the cultural field. Most of the artistic representations have been created by the British artists who opposed Great Britain's exit from the EU. Bansky, an anonymous graffiti artist from Great Britain made in May 2017 a mural painting which shows a worker 
who uses a chisel to detach a star from the EU flag. The painting is located in Dover, southern England.

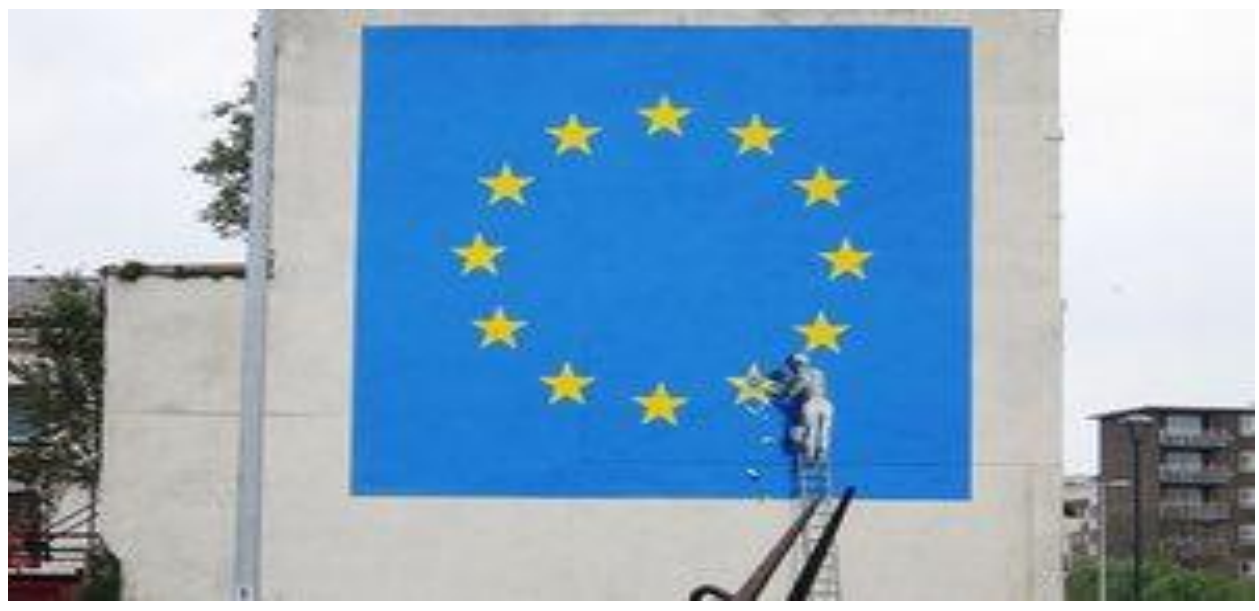

Figure 2. Banksy Brexit mural of man chipping away at EU flag appears in Dover (Petersen, 2017).

One of the first novels related to post-Brexit era was the novel "Rabbitman" written by Michael Paraskos in March 2017. According to the novel, Britain's vote to leave the EU was the result of a pact with the devil, and consequently the British society will collapse and become dependent on food aid from the EU. The novel "Love like Blood", published in June 2017, by Mark Billingham is a thriller in which Brexit is considered to be responsible for the increasing criminal offenses based on hatred and xenophobia. In June 2017, at the National Theatre in London, the play "Brexit in my country: a work in progress" written by Caroll Ann Duffy was played for the first time. The play is centered on the goddess Britannia, concerned about the future of the British people and is, unlike the other works of British artists, closer to the Brexit side than to the anti-Brexit side, a trend that can also be seen in the documentary films about Brexit.

\section{Conclusions}

Without claiming to have exhausted the subject, however, we can conclude that Great Britain's course alongside the EU (although hindered by obstacles since the accession and 
opinion differences throughout the partnership) has been beneficial for both the United Kingdom's development and for the EU's budget, which will decrease considerably after the "strange" British partner withdraws definitively. Although Brexit is a difficult step, the EU's course will continue on the same path after finishing the procedures, aiming at widening and deepening the European integration. Although we do not have a complete overview of how British-European relations will look, we can see a common determination on the part of the two actors to maintain beneficial collaborations for both sides in the future. Time pressure, however, is starting to make a difference and Great Britain will have to adopt concrete negotiating positions in order to have the necessary answers to Brexit's stringent questions as quickly as possible. For the other side, EU has to be pay more attention to the "lesser Europe" movement wich culminated with the Brexit, by bringing more arguments "in favor of the pragmatism of the slogan Unity in Diversity" (Barna and Maniu, $2016: 20$ ).

\section{Bibliography}

1. (2017), A cincea rundă de negocieri UE-Marea Britanie, pe fondul unui context politic dificil la Londra, Adevărul.ro, 9 October, available at: http://adevarul.ro/international/europa/brexit-cincea-runda-necocieri-ue-marea-britaniefondul-unui-contex-politic-dificil-londra-1_59db402e5ab6550cb8f575c5/index.html, [accessed on: 01/10/2017].

2. (1967), De Gaulle says <non> to Britain - again, BBC: On This Day, 1950-

2005, 27th Nov., available at: http://news.bbc.co.uk/onthisday/hi/dates/stories/november/27/newsid_4187000/4187714.s tm, [accessed on: 01/10/2017].

3. (1973), Britain joins the EEC, BBC: On This Day, 1950-2005, available at: http://news.bbc.co.uk/onthisday/hi/dates/stories/january/1/newsid_2459000/2459167.stm, [accessed on: 01/10/2017]. 
4. BARNA, R., MANIU, M. (2016) Regional Identity: A Prerequisite for any Efficient Change of the Regional Economic Structure, On-line Journal Modelling the New Europe, no. 20 , pp. 3-23.

5. BECKER S.O., FETZER T. and NOVY, D. (2016), Who voted for Brexit? A Comprehensive District-Level Analysis. CAGE Working Paper 305, available at: http://www.trfetzer.com/who-voted-for-brexit/, [accessed on: 01/10/2017].

6. DAHL, M., SKOMOROKHOVA, Y. (2017) The Balance of Power in the European Union after Brexit, Studia Universitatis Babeș-Bolyai, Studia Europaea, LXII, no. 3, pp. 267-284.

7. DRĂGHICI, M. (2017), Prima rundă de negocieri pentru Brexit. Ce au convenit Comisia Europeană și Marea Britanie, Gândul, 20 June, available at: http://www.gandul.info/international/prima-runda-de-negocieri-pentru-brexit-ce-auconvenit-comisia-europeana-si-marea-britanie-16491261, [Accessed on: 10/10/2017].

8. ELECTORAL COMMISSION OF THE GREAT BRITAIN'S REFERENDUM, (2016), available at: https://www.electoralcommission.org.uk, [accessed on: 10/10/2017].

9. IONESCU, G. (2017), UE și Marea Britanie încep a doua rundă de negocieri pe tema Brexit-ului, Agerpres, 17 July, available https://www.agerpres.ro/externe/2017/07/17/ue-si-marea-britanie-incep-luni-a-douarunda-de-negocieri-pe-tema-brexit-ului-04-17-56, [accessed on: 10/10/2017].

10. MAY A. (1998), Britain and Europe since 1945 (Seminar Studies in History), London: Routledge, available at: https://books.google.ro/books?id=Y9EFBAAAQBAJ\&printsec $=$ frontcover $\& d q=$ Britain + and + Europe + since $+1945 \& \mathrm{hl}=\mathrm{en} \& \mathrm{sa}=\mathrm{X} \& \mathrm{ved}=0 \mathrm{ahUKEwilxuukx} 83 \mathrm{YAhXRxqQKHVfKB}$ QkQ6AEIMDAB\#v=onepage \&q=Britain\%20and\%20Europe\%20since\%201945\&f=fals, [accessed on: 10/10/2017].

11. OXFORD DICTIONARY, available at: https://en.oxforddictionaries.com/definition/brexit, [accessed on: 10/10/2017].

12. PĂUN, D. (2016) A European Union à la Carte? Reflections on Structural Administrative Reforms and Economic Governance, On-line Journal Modelling the New Europe, no. 20, pp. 80-90. 
Issue no. $24 / 2017$

13. POPESCU, S., ARUȘTEI S. (2017), Noua rundă de negociere a Brexit-ului: UE cere Londrei să își clarifice poziţiile și britanicii acuză inflexibilitatea europenilor. Agerpres, 28 August, available at: https://www.agerpres.ro/externe/2017/08/28/noua-runda-denegociere-a-brexitului-ue-cere-londrei-sa-si-clarifice-pozitiile-si-britanicii-acuzainflexibilitatea-europenilor-19-50-06, [accessed on: 10/10/2017].

14. RAJINI, V. (2010), Michael Foot: What did the <longest suicide note> say? BBC News Magazine. BBC, available at: http://news.bbc.co.uk/2/hi/uk_news/magazine/8550425.stm, [accessed on: 17/10/2017].

15. STEPHAN, G. (1998), An Awkward Partner: Britain in the European Community. New York: Oxford University Press, available at: https://books.google.ro/books?hl=ro\&id=PnDsAAAAMAAJ\&dq=An+Awkward+Partner $\% 3 \mathrm{~A}+$ Britain+in+the+European+Community $\&$ focus $=$ searchwithinvolume $\& q=A n+A w k$ ward+Partner\%3A+Britain+in+the+European+Community, [accessed on: 17/10/2017].

16. Mason, R. (2014), 10 key lessons from the European elections result, The Guardian, 26 May, available at: https://www.theguardian.com/politics/2014/may/26/10-key-lessonseuropean-election-results, [accessed on: 17/10/2017].

17. Petersen, H. E (2017), Banksy Brexit mural of man chipping away at EU flag appears in Dover, The Guardian, 8 May, available at: https://www.theguardian.com/artanddesign/2017/may/07/banksy-brexit-mural-dover-euflag, [accessed on: 17/10/2017].

18. TOMA I. (2017), The Economist: Ce se va întâmpla după invocarea Articolului 50 din Tratatul de la Lisabona. News.ro, 29 March, available at: https://www.news.ro/externe/the-economist-ce-se-va-intampla-dupa-invocareaarticolului-50-din-tratatul-de-la-lisabona-1922400029002017031516876050, [accessed on: 20/10/2017].

19. TRACI, L. (2017), Brexit: o nouă rundă de negocieri UE-Marea Britanie, în așteptarea unor propuneri concrete. Agerpres, 25 September, available at: https://www.agerpres.ro/externe/2017/09/25/brexit-o-noua-runda-de-negocieri-ue-mareabritanie-in-asteptarea-unor-propuneri-concrete--09-16-45, [accessed on: 20/10/2017]. 
Issue no. $24 / 2017$

20. WILDING, P. (2012), Stumbling towards the Brexit, available at: http://blogactiv.eu/blog/2012/05/15/stumbling-towards-thebrexit, [accessed on: 20/10/2017]. 